\title{
Thyroid hormone and seasonal rhythmicity
}

\author{
Hugues Dardente ${ }^{1,2,3,4}$ *, David G. Hazlerigg ${ }^{5}$ and Francis J. P. Ebling ${ }^{6}$ \\ 1 Physiologie de la Reproduction et des Comportements, INRA, UMR085, Nouzilly, France \\ ${ }^{2}$ CNRS, UMR7247, Nouzilly, France \\ ${ }^{3}$ Université François Rabelais de Tours, Tours, France \\ ${ }^{4}$ Institut français du cheval et de l'équitation, Nouzilly, France \\ ${ }^{5}$ Department of Arctic and Marine Biology, University of Tromsø, Tromsø, Norway \\ ${ }^{6}$ School of Life Sciences, University of Nottingham, Nottingham, UK
}

\section{Edited by:}

Frédéric Flamant, Ecole Normale

Supérieure de Lyon, France

\section{Reviewed by:}

Valerie Simonneaux, Centre National de la Recherche Scientifique, France Sulay Tovar, University of Cologne, Germany

${ }^{*}$ Correspondence:

Hugues Dardente, INRA, UMR85

Physiologie de la Reproduction et des

Comportements, CNRS, UMR7247,

Université François Rabelais de Tours,

IFCE, F-37380 Nouzilly, France

e-mail: hdardente@tours.inra.fr
Living organisms show seasonality in a wide array of functions such as reproduction, fattening, hibernation, and migration. At temperate latitudes, changes in photoperiod maintain the alignment of annual rhythms with predictable changes in the environment. The appropriate physiological response to changing photoperiod in mammals requires retinal detection of light and pineal secretion of melatonin, but extraretinal detection of light occurs in birds. A common mechanism across all vertebrates is that these photoperiod-regulated systems alter hypothalamic thyroid hormone (TH) conversion. Here, we review the evidence that a circadian clock within the pars tuberalis of the adenohypophysis links photoperiod decoding to local changes of $\mathrm{TH}$ signaling within the medio-basal hypothalamus $(\mathrm{MBH})$ through a conserved thyrotropin/deiodinase axis. We also focus on recent findings which indicate that, beyond the photoperiodic control of its conversion, TH might also be involved in longerterm timing processes of seasonal programs. Finally, we examine the potential implication of kisspeptin and RFRP3, two RF-amide peptides expressed within the MBH, in seasonal rhythmicity.

Keywords: seasonality, reproduction, pars tuberalis, melatonin rhythm, kisspeptins, RF-amide, GnRH neurons

\section{INTRODUCTION}

Seasonality is a critical property of most organisms. At temperate latitudes, photoperiod is the main synchronizer of seasonal functions. Photoperiodism defines the use of the annual cycle of day and night length to coordinate functions such as reproduction, fattening, hibernation, and migration with predictable changes in the environment, for example in food availability or climatic conditions. Seasonal changes in physiology and behavior typically are innately timed long-term processes, requiring weeks or months to wax and wane. Therefore, additional to photoperiodic readout mechanisms, living creatures have evolved endogenous long-term timing devices, which allow them to anticipate forthcoming seasonal changes. In the most extreme cases, cycles of about 365 days recur for years in animals kept under constant photoperiods; such so-called circannual rhythms exist in a variety of birds and longer-lived mammals.

Species with relatively short life spans such as voles and hamsters usually do not display circannual rhythms, but their seasonal cycles also comprise an endogenously generated part, which corresponds to the overwintering period and allows timely emergence from the burrow and reproductive recrudescence in early spring. Endogenous long-term timing is commonplace in vertebrates but its mechanistic basis remains mysterious [for reviews, see Ref. (16)]. Here we review findings, essentially in birds and mammals, which clarify the mechanisms of photoperiodic readout and provide a rationale for the seasonal control of thyroid hormone $(\mathrm{TH})$ metabolism within the hypothalamus.
PHOTOPERIODISM: MELATONIN AND THE PARS TUBERALIS

The crucial role of melatonin in mammalian photoperiodism has been established in many species including hamsters, ferrets, and sheep (7-9). Within the pineal, melatonin is produced and released during the night and therefore constitutes an internal neurochemical representation of photoperiod. Timed melatonin-infusion experiments established that duration is the key parameter of the melatonin pattern that triggers the photoperiodic response [for review, see Ref. (10)]. In order to map central binding sites, autoradiography with 2-iodo-melatonin was used in a wide range of mammals (11). Surprisingly, across all species the highest density of melatonin-binding sites was found in the pars tuberalis (PT), a region of the pituitary stalk apposed to the median eminence. The suprachiasmatic nuclei $(\mathrm{SCN})$ also showed moderate labeling in most species while many brain nuclei showed weak to moderate labeling, with very little species overlap [for reviews, see Ref. $(12,13)]$. The presence of melatonin receptors within the SCN was consistent with the effects of melatonin on daily timing in mammals (14). Conversely, since the PT was the only neuroendocrine structure labeled in the highly photoperiodic ferret, a role in seasonality was anticipated (15). However, melatonin-binding sites were also disclosed within the PT of species, which are not overtly photoperiodic such as mouse, rat, and human.

Melatonin-binding studies also led to the recognition that the binding site(s) for melatonin was a classical GPCR, with picomolar affinity for its ligand. In mammals, two high-affinity melatonin receptors (MT1 and MT2) were cloned $(16,17)$. Subsequent studies showed that MT1 is the predominant subtype, both necessary 
and sufficient to mediate the photoperiodic effect of melatonin (18-22). The number of central sites expressing melatonin receptors as revealed by in situ hybridization was comparatively more restricted - mostly the PT and the SCN - than that observed with melatonin-binding studies. This may reflect the difference in sensitivity of the techniques and/or the existence of a low-affinity melatonin-binding site. The latter would be physiologically irrelevant, and probably corresponds to quinone reductase 2 rather than a true melatonin receptor (23).

\section{MELATONIN-DEPENDENT TSH RELEASE IN THE PARS TUBERALIS}

The PT is the most rostral part of the adenohypophysis. Many reviews detailing the ontogeny, morphology, and immunohistochemical characteristics of the PT are available (24-28). The PT was once considered an "undifferentiated embryological remnant of the hypophysis" whose "only function is to provide mechanical support role for the hypothalamo-hypophyseal portal vessels" [see Ref. (29)]. However, its location and anatomical features pleaded in favor of a specific role: the PT extends along the ventral aspect of the median eminence, surrounds the pituitary stalk in its most caudal part, and is in contact with nerve endings of the median eminence and capillaries of the pituitary primary plexus.

The PT is phylogenetically conserved in tetrapods, but is generally absent in fish (30), and consists of endocrine cells, which exhibit early secretory activity compared to the pars distalis (PD). Three different cell types occur in the PT: (i) follicular cells; (ii) gonadotropes, which constitute $\sim 10 \%$ of the endocrine PT cells, have dense-core granules and occur mostly in the caudal PT (known as the zona tuberalis); (iii) PT-specific cells, which are virtually agranular thyrotropes and constitute $\sim 90 \%$ of endocrine PT cells. The PT gonadotropes appear identical to those in the PD, while shape and ultrastructure of PT-specific thyrotropes differ strikingly from those in the PD $(24,25)$. These thyrotropes were therefore suspected to be a peculiar pituitary endocrine cell type, possibly producing a novel glycoprotein ["tuberalin," Ref. (31)]. These cells exhibit early secretory activity compared to PD endocrine cells (32). This depends upon the induction of $T \operatorname{sh} \beta$ transcription by a transcription factor consequently called TEF [Thyrotroph Embryonic Factor; Ref. (33)].

Based on ultrastructure and immunohistochemistry, these PTspecific thyrotropes were predicted to be melatonin-responsive, a prediction which has since been validated $(34,35)$. TSH immunoreactivity within these cells displays dramatic melatonindependent photoperiodic changes, with high and low levels under long (LP) and short photoperiod (SP), respectively $(36,37)$. Finally, the TSH produced by these PT-specific thyrotropes may be identical to that produced by the $\mathrm{PD}$, but the transcriptional control of the Tsh $\beta$ gene in the two populations differs since PT thyrotropes do not express receptors for either TRH or TH (38). Hence, Tsh $\beta$ expression by PT-specific thyrotropes is disconnected from the classical hypothalamic-pituitary-thyroid axis; instead it depends upon melatonin.

However, considering the Harris dogma of a descending flow of information from the hypothalamus to the pituitary, a role for PT-derived TSH was not forthcoming. Rather, it was assumed that, should the PT play a role in seasonality, it would most probably be to release tuberalin(s) in the pituitary portal plexus, which would then target the PD. This might be the case for the seasonal control of the lactotropic axis, even though the mechanism is unclear (39). This aspect will not be considered further here as it has been discussed elsewhere (28, 40-42).

\section{THYROID HORMONE SIGNALING IN SEASONAL CYCLES AN OVERVIEW}

The pioneering work of Benoit on ducks in the 1930s revealed that the thyroid gland is mandatory for seasonal transitions in reproductive states, a finding which applies to a wide range of vertebrates [reviewed by Nicholls et al. (43); Hazlerigg and Loudon (44); Yoshimura (45)]. Thyroidectomy prevents the cessation of breeding in starlings (46), quail (47), and sheep [Ref. (43, 48, 49); for review, see Ref. (50)]. In rams, thyroidectomy during the nonbreeding season almost immediately reactivates the gonadotropic axis (51). Therefore, TH appeared to transmit the message of long-day lengths. Microimplants releasing small amount of $\mathrm{TH}$ were then surgically placed within the brain of the ewe $(52,53)$, which revealed that $\mathrm{TH}$ acts centrally, and most likely within the medio-basal hypothalamus $(\mathrm{MBH})$, to impact seasonal reproduction. Studies in Siberian hamsters using a similar microimplants approach further showed that other seasonal axes are also controlled by central actions of T3: providing T3 directly within the $\mathrm{MBH}$ overrides the SP-induced inactivation of the gonadotropic axis (54) and triggers premature gonadal recrudescence in SPexposed animals. T3 implants also override SP-induced seasonal inappetence, weight loss, and expression of torpor [Ref. (55); see Figure 1]. Similar outcomes are found when T3 is provided by daily subcutaneous injections to SP-exposed hamsters (56). In contrast to these effects on reproduction and energy metabolism, T3 implants do not impact the lactotropic axis, consistent with a distinct mechanism of control $(57,58)$ while not incompatible with a common melatonin target tissue as discussed later.

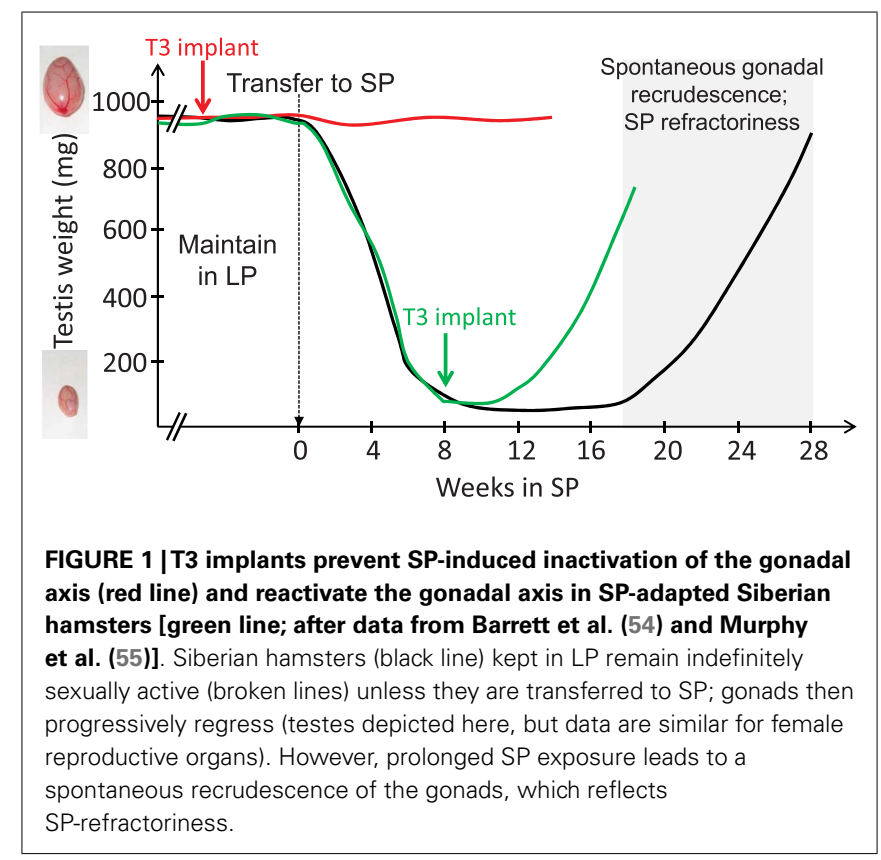


These observations added to the well-documented role of $\mathrm{TH}$ in key transitions between life cycles, such as metamorphosis in amphibians and developmental growth and differentiation of the mammalian brain $(59,60)$. In adults, $\mathrm{TH}$ also has key roles in the control of metabolism and thermoregulation, two processes intertwined with the seasonal reproductive cycle. The seasonal program encompasses profound and coordinated changes in behavioral, reproductive, and metabolic states (61). The finding that $\mathrm{TH}$ regulates the basal metabolic rate is not new, but the recognition that it reflects a central action within the $\mathrm{MBH}$ is very recent (62, 63). Indeed, $\mathrm{T} 3$ injection within the $\mathrm{MBH}$ suffices to promote food intake and weight gain in rats (64). Interestingly, this effect is mimicked by LP, which triggers weight gain in many species, including sheep (65). Such a process bears critical adaptive value, best exemplified in species that hibernate (e.g., groundhog) or undergo daily torpor (e.g., Siberian hamster), which have evolved a strategy to build up abdominal fat depots during spring/summer to survive the harsh winter season $(1,61)$. Photoperiodic cues and the metabolic status interact in many seasonal breeders, including sheep $(66,67)$, goats $(68,69)$, and horses $(70)$. In all these species, feeding modulates the duration of the breeding season and/or depth of the anestrus. Therefore, $\mathrm{TH}$ integrates and coordinates physiological changes, which are integral to the seasonal program.

\section{LOCAL CONTROL OF TH METABOLISM WITHIN THE MBH}

Although cold exposure activates thyroid activity, under constant ambient temperature conditions, TH concentrations do not display marked or consistent seasonal fluctuations in the plasma or cerebro-spinal fluid. Rather, fine temporal and local control of TH action is achieved through opposite actions of specific enzymes known as deiodinases (71-73). Deiodinase 2 (DIO2) converts the relatively inactive $\mathrm{T} 4$ into the active $\mathrm{T} 3$ while deiodinase 3 (DIO3) inactivates $\mathrm{T} 4$ by converting it into $\mathrm{rT} 3$, and also degrades $\mathrm{T} 3$ into T2. Very precise control of T3 concentrations is further achieved through reciprocal control of the expression and activity of these two enzymes by their ligand: a hypothyroid state up-regulates DIO2 and down-regulates DIO3, and vice-versa $(72,74,75)$.

The central expression of Dio2 is restricted to a few structures. The pineal gland is one of them (76), but the strongest expression occurs in astrocytes and tanycytes lining the third ventricle and median eminence $(77,78)$. These tanycytes also express two major TH transporters, MCT8 and OATP1c1 (79-81), and MCT8 is expressed at higher levels under SP than LP in the Siberian hamster $(82,83)$. Tanycytes are a heterogeneous and complex population of ependymal cells, which constitute a gateway between the CSF and the $\mathrm{MBH}$ and median eminence (84). In a pioneering study, Yoshimura and colleagues (85) showed that both Dio2 and Dio3 are expressed within tanycytes of the quail MBH. Crucially, the expression of these two enzymes displays opposite regulation by photoperiod: Dio2 is highly expressed under LP while Dio3 is highly expressed under SP. This predicted a local increase of T3 content within the MBH under LP, which was validated by radioimmunoassay (85). The opposite regulation of Dio2 and Dio3 by photoperiod has since been described in sparrows and Siberian and Syrian hamsters (86-89). Importantly, the expression of Dio2 is down-regulated by melatonin, independently of sex steroids (88, 90). Melatonin is also required to trigger Dio3 expression under
SP in Siberian hamster (54). Collectively, these data provided an enzymatic means through which local T3 levels in the MBH could increase under LP.

\section{CLOSING THE LOOP: TSH OUTPUT FROM THE PT GOVERNS T3 REGULATION WITHIN THE MBH}

The PT seemed well located to mediate photoperiodic switches in Dio2-Dio3 usage. To decipher the mechanism of the photoperiodic response, Yoshimura and colleagues (91) set out an ambitious experimental set-up: hypothalamic blocks containing the $\mathrm{MBH}$ and $\mathrm{PT} /$ median eminence from quails submitted to a long-day transfer, known to activate the gonadotropic axis within $24 \mathrm{~h}$, were used for hybridization on a chicken gene chip. This revealed that the expression of two genes, Tsh $\beta$ and Eya3, is rapidly triggered by the transfer from SP to LP. A second wave of transcriptional changes was also observed for a handful of genes including Dio2 and Dio3, which displayed acute and simultaneous induction and repression, respectively. Crucially, expression of the cognate TSH receptor (TSHR) was found in tanycytes, which express the deiodinases, providing the link between TSH output from the PT and $\mathrm{T} 3$ regulation within the $\mathrm{MBH}$. The pathway was uncovered using an acute intracerebroventricular injection of TSH to SP-exposed quails, which induced Dio2 expression and led to gonadal recrudescence.

In a contemporaneous study in sheep, Hanon et al. (92) suggested this mechanism to be ancestral, since their data were similar in many respects: higher Tsh $\beta$ expression within the PT under LP than SP (see Figure 3A), expression of the TSHR within tanycytes and PT/median eminence, higher Dio2 expression under LP than SP (see Figure 3A), and TSH-dependent induction of Dio2 both in vitro and in vivo. The latter finding was not unexpected, since TSHR signals through a Gs protein, and Dio2 is a cAMPresponsive gene (93). In contrast, the MT1 receptor couples to a Gi protein and the interplay between TSHR and MT1 signaling within the PT may be part of the photoperiod decoding mechanism, at least in sheep $(92,94,95)$. Under LP, the PT therefore functions as an "indirect T3-generator," disconnected from both TRH and T3 feedback (see above).

Since these studies in quail and sheep, a similar $\mathrm{TSH} /$ deiodinases/T3 retrograde pathway (from the pituitary back to the hypothalamus, Figure 2) has been described not only in other photoperiodic species such as the European hamster (96), the Syrian hamster (97), the Siberian hamster (89), the common vole (98), but also in photoresponsive juvenile Fisher 344 rats (99) and in a melatonin-producing but non-photoperiodic CBA/N

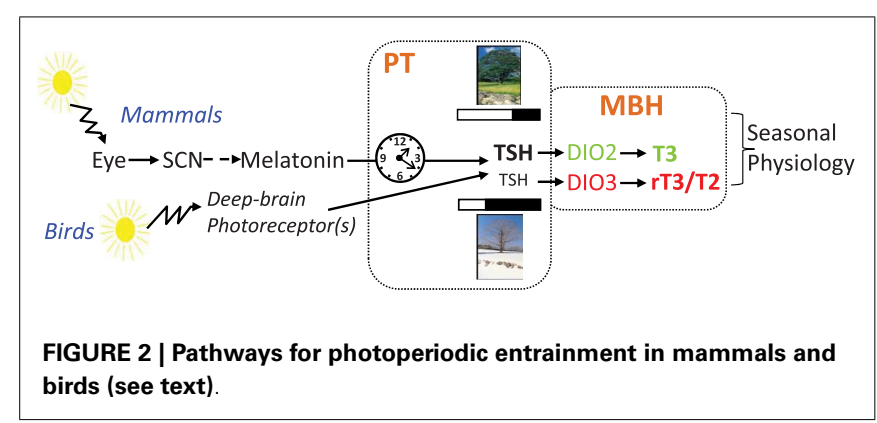




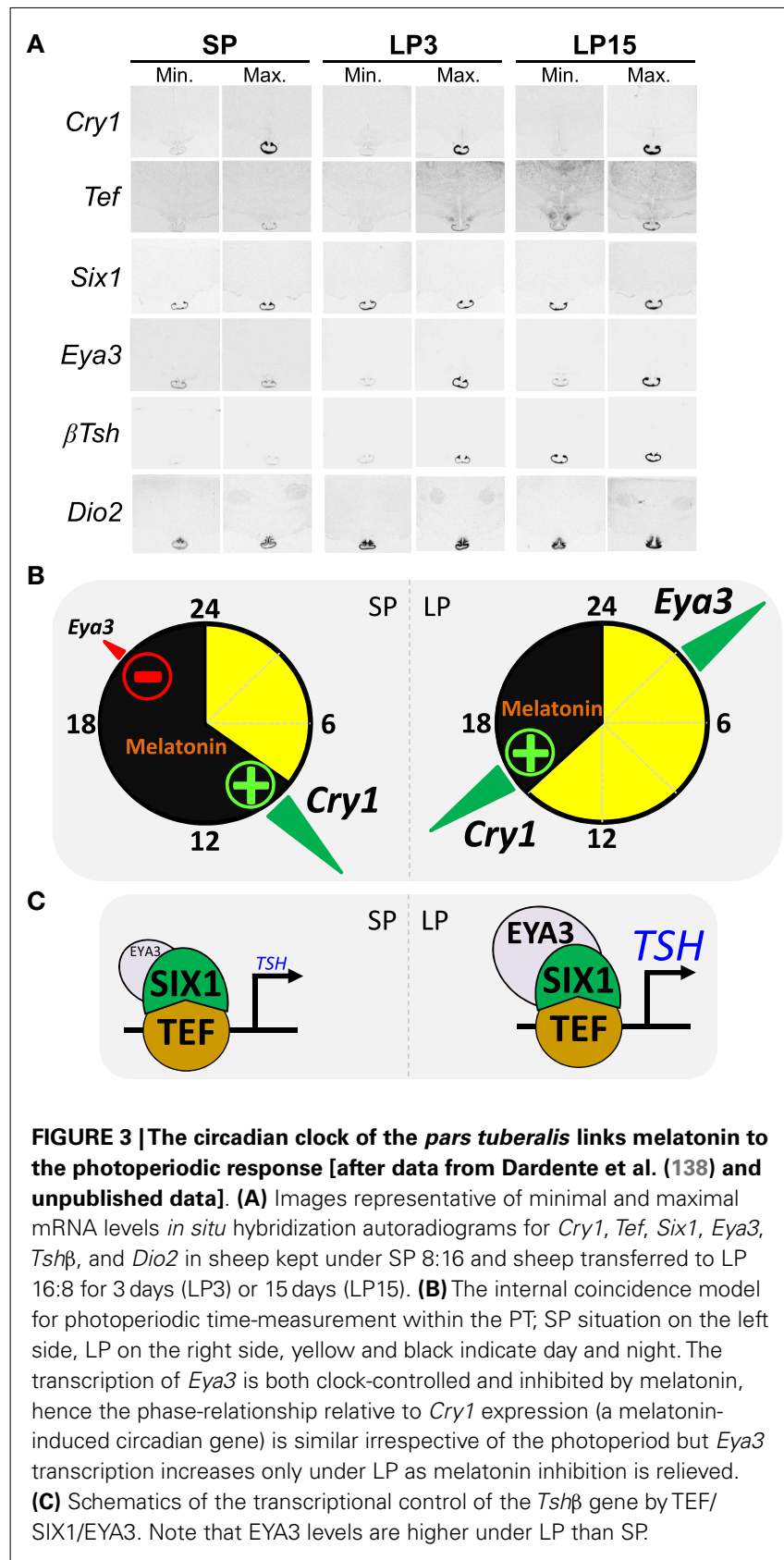

mouse strain $(22,100,101)$. Photoperiodic variations in Dio2 expression were however not observed in the non-photoperiodic Wistar rat (88). The use of murine knock-out strains confirmed that the MT1 melatonin receptor (22) and TSHR (100) are mandatory for the LP induction of Dio2 expression within tanycytes. Whether this pathway is present in all vertebrates remains to be determined (102).

As mentioned before, fish species investigated thus far do not have a distinct PT, but in masu salmon a TSH/DIO2 axis implicating the saccus vasculosus, located below the hypothalamus and caudally to the pituitary gland, has been proposed (103). However, the saccus vasculosus is absent in several species of fish such as the pike (104), which is nonetheless photoperiodic (105).
The other few studies on this matter in fish have yielded varied outcomes (106, 107). Regarding birds, studies in tits (108) and starlings (109) did not lend clear support to the model, but aspects of the experimental set-up prevent any conclusion to be drawn. For example, the studies of starlings were carried out in outdoor aviaries, so effects of fluctuating temperature on the peripheral thyroid axis may have obscured the photoperiodic regulation of DIO2 and DIO3 centrally. Finally, we are not aware of any study on this matter in either reptiles or amphibians.

\section{ENCODING AND DECODING THE PHOTOPERIODIC MESSAGE UPSTREAM OF THE PT}

Birds and mammals possess a similar mechanism to respond to photoperiod, but they perceive the photoperiodic message in different ways. In mammals, light is exclusively perceived by the retina, with a key role for ganglion cells expressing the photopigment melanopsin [for review, see Ref. (110)]. This information is relayed to the circadian clock of the SCN, which governs melatonin production by the pineal gland through a multi-synaptic sympathetic pathway. Melatonin is the mandatory messenger of photoperiod in mammals. In striking contrast, removing the eyes and suppressing melatonin by pinealectomy does not disrupt photoperiodism in birds [for reviews, see Ref. (44, 45, 111-113)]. In birds, light goes through the skull and acts directly upon hypothalamic deep-brain photoreceptors to control seasonal reproduction (Figure 2). Several photopigments expressed by different cell types, all located within the $\mathrm{MBH}$ and projecting to the PT/median eminence, are plausible candidates: VA-opsin (114), neuropsin [Opn5, Ref. $(115,116)]$, and melanopsin [Opn4, Ref. (117)]. The neurotransmitter(s) and/or neuropeptide(s) used by these cells, and how they impinge on PT thyrotropes, remain to be elucidated.

\section{WITHIN THE PT: FROM THE CIRCADIAN CLOCK TO THE SEASONAL OUTPUT}

Photoperiodic species such as quail (118) and Siberian and Syrian hamsters $(119,120)$ measure photoperiod length with remarkable accuracy. In these three species, reproduction switches off when the photoperiod is shorter than $12.5 \mathrm{~h}$. The narrow photoperiod range over which physiological changes occur is one of the lines of evidence implicating some sort of daily timing device. The concept that circadian clock(s), clocks with a period of about $24 \mathrm{~h}$, control seasonal timing is indeed not novel $(120,121)$.

The genetic and molecular bases and organization of circadian clocks have been recently identified (122-124). These clocks are not only located within the SCN, but are present in virtually every tissue and cell where they impact "local" physiology. The PT is no exception as it expresses a full set of clock genes and displays persistent circadian rhythmicity in vitro [Ref. (125-127); for review, see Ref. (28)]. The SCN and peripheral clocks share fundamental characteristics: they are cell-autonomous and self-sustained. However, individual cellular clocks within peripheral tissues rapidly become desynchronized and exhibit phase drifting in the absence of regular resetting by cues emanating, directly or indirectly, from the SCN. These cues include inputs from the autonomic nervous system, temperature cycles, and humoral factors such as glucocorticoids and melatonin. 
The PT can be defined as a melatonin-dependent circadian oscillator $(28,50)$. Resetting of the PT clock by melatonin requires acute induction of Cry1 expression [Ref. (128, 129), see Figure 3A]; CRY1 being a key repressor of the circadian clock (130-132). The acute induction of Cryl expression involves EGR1-like factors (133) and the transcription factor NPAS4 (134, 135). In sheep, Cryl expression remains tightly linked to the onset of melatonin secretion and by implication night onset, irrespective of the duration of the day length [Ref. (136), see Figure 3B]. Interestingly, light given during the night induces Cryl expression within the quail PT (137), which suggests a phylogenetically conserved role for Cryl in the photoperiodic resetting of the PT clock.

How do we connect melatonin resetting of the PT clock with differential photoperiodic output of TSH and seasonal reproduction? The expression of the transcriptional co-activator EYA3 within the ovine PT displays large photoperiodic changes in both phase and amplitude [Ref. $(39,138)$; see Figure 3A]. Interestingly, Eya3 was the other gene (besides $T s h \beta$ ) immediately induced in the quail PT during the first long-day release experiment (91). We therefore investigated the transcriptional control of Eya3 and searched for a link between inductions of both genes. The expression of Eya3 is clock-controlled, through conserved DNA binding motifs within its promoter, and therefore phase-locked to that of the circadian clock [Ref. (138), see Figure 3B]. Because of this, expression peaks during the night under SP but during the day under LP. The amplitude of the peak is higher under LP than SP because melatonin suppresses Eya3 expression, a suppression which can only occur in SP-exposed animals [Ref. (138); see Figure 3B]. Finally, in vitro data showed that induction of $T \operatorname{sh} \beta$ expression is triggered by the circadian-controlled transcription factor TEF (33), which then recruits the co-activators SIX1 and EYA3. This leads to a marked increase in transcription under LP due to higher levels of EYA3 [Ref. (102, 138), Figures 3B,C]. A critical role for SIX1/EYA3, but not TEF, in the photoperiodic control of Tsh $\beta$ transcription in the mouse PT has been proposed (139, 140).

\section{IS T3 OUTPUT SUFFICIENT TO ELICIT THE FULL SPECTRUM OF SEASONAL CHANGES?}

The data reviewed so far are consistent with a crucial role for the TSH output of the PT in driving seasonal changes in T3 availability within the $\mathrm{MBH}$. However, swings in TSH/T3 may not be sufficient to elicit all seasonal changes. As mentioned before, since control of the lactotropic axis does not depend on T3 [for review, see Ref. (50)], complementary mechanisms are indeed expected. Neuromedin U $(89,141)$, histamine, and VGF secretion $(82,142,143)$ may mediate seasonal effects on body weight and metabolism since their synthesis and cognate receptors display expression patterns and seasonal changes reminiscent of those seen for TSH/TSHR. However, since TSH infusion in SP-adapted Siberian hamster restores hypothalamic expression of somatostatin and body weight to LP levels (144), Neuromedin U, histamine, or VGF may be dispensable.

Retinoic acid signaling is also likely to be involved as retinoic acid receptors, transporters, and associated binding proteins display prominent photoperiodic regulation in the ependymal cell layer and posterior arcuate nucleus of Siberian hamsters and juvenile Fischer F344 rats (142, 145, 146). Interestingly, the retinoic $\mathrm{X}$ receptor $(\mathrm{RXR})$ can heterodimerize with either the TH receptors $(\mathrm{THR} \alpha / \mathrm{THR} \beta)$ or the retinoic acid related receptor (RAR). The target genes and downstream pathways governed by THR and RAR diverge, and therefore the photoperiodic regulation of RXR/RAR may fine-tune the seasonal adaptation of the metabolic status. From a more general standpoint, the notion that tanycytes coordinate a host of seasonal neuroendocrine cycles including reproduction, metabolism, and hibernation is emerging rapidly [Ref. (147, 148); for reviews, see Ref. $(61,149,150)]$.

\section{PHOTOPERIODIC TIMING AND THE CIRCANNUAL CLOCK: T3 AS A UNIFYING COMPONENT?}

As mentioned earlier, whether species are classified as photoperiodic (e.g., Siberian and Syrian hamsters) or circannual (e.g., sheep), part of the seasonal cycle is generated endogenously. Hamsters and sheep maintained under constant SP do spontaneously revert to the opposite physiological state after several months. This phenomenon, referred to as "SP refractoriness," is typical of an interval timer/hourglass $(5,151)$. In contrast, sheep but not Siberian or Syrian hamsters, also display refractoriness to LP. Whether this species difference reflects fundamentally divergent underlying mechanisms is questionable. Indeed, Follett and Nicholls (47) proposed years ago that "it may well be that essentially identical physiological mechanisms underlie the photoperiodic responses of a wide range of vertebrates and that very minor modifications of these can cause surprisingly large (though superficial) changes in the overt responses of the animal in terms of reproduction." These authors devised a model, based on differences in threshold sensitivity, which rationalizes the LP refractoriness process (see Figure 4). There are indeed similarities between the photoperiodic control of the seasonal program in photoperiodic and circannual species $(43,50,152)$. Siberian or Syrian hamsters and sheep might therefore exemplify "variations on a theme" rather than fundamentally different models.

Because $\mathrm{TH}$ is involved in many long-term life cycles events, it seems plausible that photoperiod-induced changes in T3 levels may also trigger more profound long-term changes, culminating weeks to months later. In particular, $\mathrm{TH}$-induced plasticity and

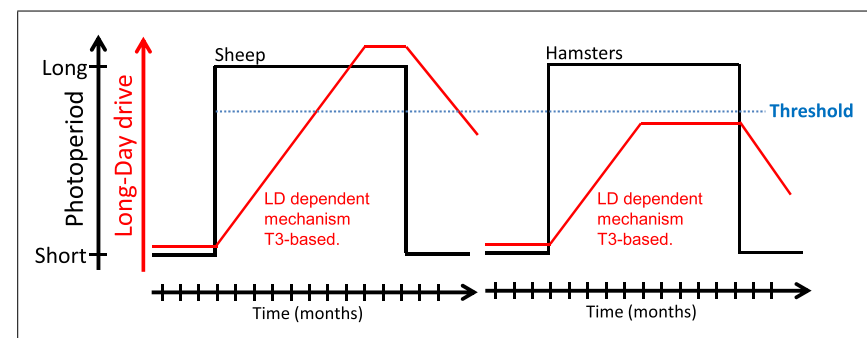

FIGURE 4 | A model for long-day refractoriness [adapted from Figure 2 in Ref. (152)]. In sheep (left panel) and hamsters (right panel), exposure to long days (black line) leads to the development of a mechanism of unknown nature, most likely T3-dependent (red line). In sheep, the long-day drive eventually exceeds a "threshold" (blue dotted line); the animal then becomes refractory to long days and spontaneously reverts to an SP phenotype. In hamsters, the long-day drive never exceeds the threshold and the animal displays the LP phenotype indefinitely; exposure to SP is mandatory to get the SP physiological state. 
cell-cycle related events have long time constants, which appear compatible with seasonal cycles $(6,153)$. Recent data in sheep demonstrate a photoperiodic gating of cell division within the PT and ependymal cells of the $3 \mathrm{~V}$ and are consistent with this scheme (154-156). Nevertheless, whether photoperiodic gating of cell division depends on $\mathrm{TH}$ and/or is involved in seasonal transitions remains to be established.

To address a potential role for TH turn-over beyond the photoperiodic response, we investigated the expression of Tsh $\beta$ and Dio2/Dio3 within the MBH of sheep under distinct physiological states: LP, LP refractory (LPR) obtained after prolonged LP exposure, SP and SP refractory (SPR) obtained after prolonged SP exposure (157). The expressions of Tsh $\beta$ and Dio 2 were diminished in LPR compared to LP animals but remained low in SP and SPR animals. The expression of Dio3 was high in SP but very low in all other photoperiodic conditions, most notably under SPR; so the expression of Dio3 under SP is transient (see Figure 5A).

Therefore, a diminished TSH output may cause the LPR state, while development of the SPR state would be disconnected from it. This would be consistent with the hourglass properties of the SPR mentioned before. However, changes in Dio2/Dio3 may reflect an indirect effect of photoperiod: within the $\mathrm{MBH}$, the local hyperthyroid state triggered by persistent LP exposure would eventually cross a certain threshold, thereby triggering Dio3 induction and Dio2 down-regulation $(72,74,75)$. Following this, T3 levels would

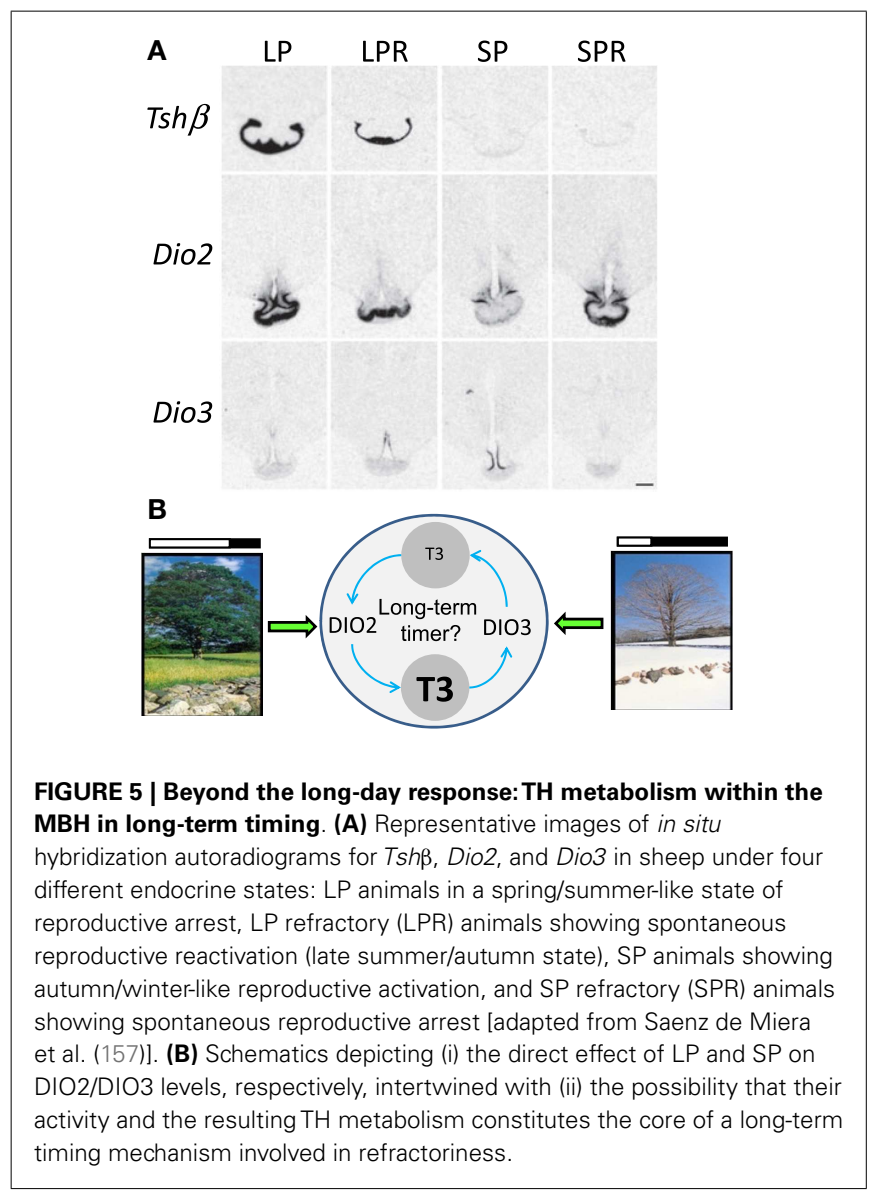

be cleared by DIO3, ultimately leading to the demise of Dio3 expression; LP exposure would then somehow be required to induce Dio2 once more and prime a new cycle. This LP requirement to prime the seasonal sequence may explain why circannual cycles in sheep are most obvious under constant LP (50).

Interestingly, Syrian hamsters in SPR state do not exhibit spontaneous reactivation of Dio2 expression (88) while Siberian hamsters do (83). Furthermore, Siberian hamsters express Dio3 upon transfer from LP to SP but its expression is not sustained through time $(54,83,87)$, similar to what occurs in sheep (157). Therefore, transient Dio3 expression under SP appears as a common feature and may explain why Dio3 expression has not been observed in Syrian hamster (54). Even though the relative variations of Dio2 and Dio3 differ between species (e.g., Siberian vs. Syrian hamster) the central tenet remains the same: T3 levels are higher within the $\mathrm{MBH}$ under LP compared to SP (158). Furthermore, TH metabolism within the $\mathrm{MBH}$ may not only intervene in the photoperiodic response but may also be integral to longer-term timing processes such as circannual rhythms (see Figure 5B).

\section{CONCLUSION}

At this stage several outstanding questions remain: first, since the same TSH/deiodinase/T3 pathway is triggered by LP not only in long-day breeders (e.g., hamsters and quail) but also in shortday breeders (e.g., sheep) and non-photoperiodic species (e.g., mouse), how do we get opposite responses, or no response at all, of the hypothalamic-pituitary-gonadal axis? This is particularly intriguing because the increased intra-hypothalamic availability of $\mathrm{TH}$ is uniformly linked to an anabolic state across seasonal species. Second, through which mechanisms do local changes of T3 within the $\mathrm{MBH}$ ultimately impinge on gonadotropin-releasing hormone neurons? Pertinent to this second question, the MBH hosts two cell populations expressing RF-amide peptides which have attracted particular attention: neurons of the arcuate nucleus, which express Kiss1 and neurons of the VMH/DMH, which express the Rfrp precursor. The concept that these RF-amide peptides are involved in seasonal breeding has been the topic of several excellent reviews $(50,158-161)$ and we will therefore only briefly review the most recent and salient findings.

Kisspeptin is a very potent GnRH secretagogue and governs most aspects of reproduction in mammals including sexual differentiation, steroid-dependent gonadotropin release, puberty onset, and the control of fertility by metabolic cues $(162,163)$. Interestingly, the annual onset of fertility in photoperiodic species had been compared to a reoccurrence of puberty, and common underlying processes were anticipated $(2,164,165)$. Kisspeptin therefore appeared a prime candidate for the integration of photoperiodic and metabolic cues across the seasonal program, a prediction which has now received strong support (159-161).

In contrast to kisspeptin, the exact role(s) of peptides derived from the Rfrp precursor, RFRP1 and RFRP3, remain(s) unclear (160). RFRP3 may modulate feeding and various stress responses $(166,167)$. In the context of breeding, RFRP3 inhibits GnRH in sheep [Ref. (168), but see Ref. (169)] but inhibits or activates GnRH in Syrian and Siberian hamsters, depending on the photoperiod $(170,171)$. The Rfrp gene is orthologous to avian $G n I H$, which gives rise to gonadotropin inhibitory hormone (GnIH), 
a peptide with well-characterized inhibitory effects upon the gonadotropic axis in birds (172). Interestingly, there is no avian ortholog of the Kiss1 (or Kiss2) gene (173), which implies that the concept of a balance between KISS1 and RFRP3 in governing GnRH secretion in mammals (174) does not apply to birds.

Both Kiss 1 and Rfrp expression display marked photoperiodic, melatonin-dependent, changes in mammals $(159,160,175)$. Even though melatonin receptors have been localized to several hypothalamic nuclei it seems likely that the photoperiodic control over Kiss 1 and Rfrp is indirect [see above, Ref. $(50,145,161)]$. In this context, a role for PT-derived TSH appeared plausible. In a landmark study, Klosen et al. (144) showed that intracerebroventricular delivery of TSH in Siberian and Syrian hamsters induces Dio2 expression within ependymal cells, restores expression of Kiss1 and Rfrp to their LP levels and, most importantly, triggers reactivation of the gonadal axis. Furthermore, Henson et al. (176) showed that T3 injections to SP-adapted Siberian hamsters reactivated the gonadotropic axis, thereby confirming prior data (see Section "An Overview" and Figure 1), but also led to LP-like levels of RF-amide peptides within the $\mathrm{MBH}$.

Therefore, even though a theoretical possibility exists that another TSH-dependent - but T3-independent pathway-leads to seasonal changes of the reproductive axis, the most parsimonious model is one in which T3 action on RF-amide neurons link the photoperiodic production of TSH within the PT to the seasonal control of GnRH secretion.

\section{ACKNOWLEDGMENTS}

Hugues Dardente is supported by a Marie Curie Career Integration Grant from the FP7-People-2012 program. Hugues Dardente wishes to thank Paul Pévet (INCI, Strasbourg, France) for continuing support and exciting discussions and Olivier Kah (Rennes, France) for sharing ideas about photoperiodism in fish.

\section{REFERENCES}

1. Davis DE. Hibernation and circannual rhythms of food consumption in marmots and ground squirrels. Q Rev Biol (1976) 51:477-514. doi:10.1086/409594

2. Lincoln GA, Short RV. Seasonal breeding: nature's contraceptive. Recent Prog Horm Res (1980) 36:1-52.

3. Goldman BD, Darrow JM. The pineal gland and mammalian photoperiodism. Neuroendocrinology (1983) 37:386-96. doi:10.1159/000123579

4. Karsch FJ, Bittman EL, Foster DL, Goodman RL, Legan SJ, Robinson JE. Neuroendocrine basis of seasonal reproduction. Recent Prog Horm Res (1984) 40:185-232.

5. Zucker I. Circannual rhythms. In: Takahashi JS, Turek FW, Moore RY, editors. Handbook of Behavioural Neurobiology, Circadian Clocks. (Vol. 12), New York: Kluwer/Plenum (2001). p. 511-28.

6. Lincoln GA, Hazlerigg DG. Mammalian circannual pacemakers. Soc Reprod Fertil Suppl (2010) 67:171-86.

7. Reiter RJ. Evidence for refractoriness of the pituitary-gonadal axis to the pineal gland in golden hamsters and its possible implications in annual reproductive rhythms. Anat Rec (1972) 173:365-71. doi:10.1002/ar.1091730311

8. Carter DS, Herbert J, Stacey PM. Modulation of gonadal activity by timed injections of melatonin in pinealectomized or intact ferrets kept under two photoperiods. J Endocrinol (1982) 93:211-22. doi:10.1677/joe.0.0930211

9. Bittman EL, Dempsey RJ, Karsch FJ. Pineal melatonin secretion drives the reproductive response to daylength in the ewe. Endocrinology (1983) 113:2276-83. doi:10.1210/endo-113-6-2276

10. Bartness TJ, Powers JB, Hastings MH, Bittman EL, Goldman BD. The timed infusion paradigm for melatonin delivery: what has it taught us about the melatonin signal, its reception, and the photoperiodic control of seasonal responses? J Pineal Res (1993) 15:161-90. doi:10.1111/j.1600-079X.1993.tb00903.x
11. Vanecek J, Pavlik A, Illnerova H. Hypothalamic melatonin receptor sites revealed by autoradiography. Brain Res (1987) 435:359-62. doi:10.1016/00068993(87)91625-8

12. Morgan PJ, Barrett P, Howell HE, Helliwell R. Melatonin receptors: localization, molecular pharmacology and physiological significance. Neurochem Int (1994) 24:101-46. doi:10.1016/0197-0186(94)90100-7

13. von Gall C, Stehle JH, Weaver DR. Mammalian melatonin receptors: molecular biology and signal transduction. Cell Tissue Res (2002) 309:151-62. doi:10.1007/s00441-002-0581-4

14. Pévet P, Challet E. Melatonin: both master clock output and internal timegiver in the circadian clocks network. J Physiol Paris (2011) 105:170-82. doi:10.1016/j.jphysparis.2011.07.001

15. Weaver DR, Reppert SM. Melatonin receptors are present in the ferret pars tuberalis and pars distalis, but not in brain. Endocrinology (1990) 127:2607-9. doi:10.1210/endo-127-5-2607

16. Reppert SM, Weaver DR, Ebisawa T. Cloning and characterization of a mammalian melatonin receptor that mediates reproductive and circadian responses. Neuron (1994) 13:1177-85. doi:10.1016/0896-6273(94)90055-8

17. Reppert SM, Godson C, Mahle CD, Weaver DR, Slaugenhaupt SA, Gusella JF. Molecular characterization of a second melatonin receptor expressed in human retina and brain: the Mellb melatonin receptor. Proc Natl Acad Sci US A (1995) 92:8734-8. doi:10.1073/pnas.92.19.8734

18. Weaver DR, Liu C, Reppert SM. Nature's knockout: the Mellb receptor is not necessary for reproductive and circadian responses to melatonin in Siberian hamsters. Mol Endocrinol (1996) 10:1478-87. doi:10.1210/me.10.11.1478

19. Liu C, Weaver DR, Jin X, Shearman LP, Pieschl RL, Gribkoff VK, et al. Molecular dissection of two distinct actions of melatonin on the suprachiasmatic circadian clock. Neuron (1997) 19:91-102. doi:10.1016/S0896-6273(00)80350-5

20. Jin X, von Gall C, Pieschl RL, Gribkoff VK, Stehle JH, Reppert SM, et al. Targeted disruption of the mouse Mel(1b) melatonin receptor. Mol Cell Biol (2003) 23:1054-60. doi:10.1128/MCB.23.3.1054-1060.2003

21. Cogé F, Guenin SP, Fery I, Migaud M, Devavry S, Slugocki C, et al. The end of a myth: cloning and characterization of the ovine melatonin $\mathrm{MT}(2)$ receptor. Br J Pharmacol (2009) 158:1248-62. doi:10.1111/j.1476-5381.2009.00453.x

22. Yasuo S, Yoshimura T, Ebihara S, Korf HW. Melatonin transmits photoperiodic signals through the MT1 melatonin receptor. J Neurosci (2009) 29:2885-9. doi:10.1523/JNEUROSCI.0145-09.2009

23. Nosjean O, Ferro M, Coge F, Beauverger P, Henlin JM, Lefoulon F, et al. Identification of the melatonin-binding site MT3 as the quinone reductase 2. J Biol Chem (2000) 275:31311-7. doi:10.1074/jbc.M005141200

24. Wittkowski WH, Schulze-Bonhage AH, Bockers TM. The pars tuberalis of the hypophysis: a modulator of the pars distalis? Acta Endocrinol (Copenh) (1992) 126:285-90.

25. Wittkowski W, Bockmann J, Kreutz MR, Bockers TM. Cell and molecular biology of the pars tuberalis of the pituitary. Int Rev Cytol (1999) 185:157-94. doi:10.1016/S0074-7696(08)60151-5

26. Morgan PJ. The pars tuberalis: the missing link in the photoperiodic regulation of prolactin secretion? J Neuroendocrinol (2000) 12:287-95. doi:10.1046/ j.1365-2826.2000.00459.x

27. Hazlerigg DG. What is the role of melatonin within the anterior pituitary? J Endocrinol (2001) 170:493-501. doi:10.1677/joe.0.1700493

28. Dardente H. Does a melatonin-dependent circadian oscillator in the pars tuberalis drive prolactin seasonal rhythmicity? J Neuroendocrinol (2007) 19:657-66. doi:10.1111/j.1365-2826.2007.01564.x

29. Gross DS. The mammalian hypophyseal pars tuberalis: a comparative immunocytochemical study. Gen Comp Endocrinol (1984) 56:283-98. doi:10. 1016/0016-6480(84)90043-1

30. Fitzgerald KT. The structure and function of the pars tuberalis of the vertebrate adenohypophysis. Gen Comp Endocrinol (1979) 37:383-99. doi:10.1016/00166480(79)90012-1

31. Stoeckel ME, Hindelang C, Klein MJ, Poissonnier M, Felix JM. Expression of the alpha-subunit of glycoprotein hormones in the pars tuberalis-specific glandular cells in rat, mouse and guinea-pig. Cell Tissue Res (1994) 278:617-24. doi:10.1007/s004410050253

32. Stoeckel ME, Hindelang-Gertner C, Porte A. Embryonic development and secretory differentiation in the pars tuberalis of the mouse hypophysis. Cell Tissue Res (1979) 198:465-76. doi:10.1007/BF00234191

33. Drolet DW, Scully KM, Simmons DM, Wegner M, Chu KT, Swanson LW, et al. $\mathrm{TEF}$, a transcription factor expressed specifically in the anterior pituitary during 
embryogenesis, defines a new class of leucine zipper proteins. Genes Dev (1991) 5:1739-53. doi:10.1101/gad.5.10.1739

34. Klosen P, Bienvenu C, Demarteau O, Dardente H, Guerrero H, Pevet P, et al. The mtl melatonin receptor and RORbeta receptor are co-localized in specific TSH-immunoreactive cells in the pars tuberalis of the rat pituitary. J Histochem Cytochem (2002) 50:1647-57. doi:10.1177/002215540205001209

35. Dardente H, Klosen P, Pevet P, Masson-Pevet M. MT1 melatonin receptor mRNA expressing cells in the pars tuberalis of the European hamster: effect of photoperiod. J Neuroendocrinol (2003) 15:778-86. doi:10.1046/j.1365-2826. 2003.01060.x

36. Wittkowski W, Hewing M, Hoffmann K, Bergmann M, Fechner J. Influence of photoperiod on the ultrastructure of the hypophyseal pars tuberalis of the Djungarian hamster, Phodopus sungorus. Cell Tissue Res (1984) 238:213-6. doi:10.1007/BF00215166

37. Wittkowski W, Bergmann M, Hoffmann K, Pera F. Photoperiod-dependent changes in TSH-like immunoreactivity of cells in the hypophyseal pars tuberalis of the Djungarian hamster, Phodopus sungorus. Cell Tissue Res (1988) 251:183-7. doi:10.1007/BF00215463

38. Bockmann J, Bockers TM, Winter C, Wittkowski W, Winterhoff H, Deufel $\mathrm{T}$, et al. Thyrotropin expression in hypophyseal pars tuberalis-specific cells is 3,5,3'-triiodothyronine, thyrotropin-releasing hormone, and pit-1 independent. Endocrinology (1997) 138:1019-28. doi:10.1210/en.138.3.1019

39. Dupré SM, Miedzinska K, Duval CV, Yu L, Goodman RL, Lincoln GA, et al. Identification of Eya3 and TAC1 as long-day signals in the sheep pituitary. Curr Biol (2010) 20:829-35. doi:10.1016/j.cub.2010.02.066

40. Lincoln GA, Clarke IJ, Hut RA, Hazlerigg DG. Characterizing a mammalian circannual pacemaker. Science (2006) 314:1941-4. doi:10.1126/science.1132009

41. Johnston JD. Photoperiodic regulation of prolactin secretion: changes in intra-pituitary signalling and lactotroph heterogeneity. J Endocrinol (2004) 180:351-6. doi:10.1677/joe.0.1800351

42. Dupré SM. Encoding and decoding photoperiod in the mammalian pars tuberalis. Neuroendocrinology (2011) 94:101-12. doi:10.1159/000328971

43. Nicholls TJ, Follett BK, Goldsmith AR, Pearson H. Possible homologies between photorefractoriness in sheep and birds: the effect of thyroidectomy on the length of the ewe's breeding season. Reprod Nutr Dev (1988) 28:375-85. doi:10.1051/rnd:19880304

44. Hazlerigg D, Loudon A. New insights into ancient seasonal life timers. Curr Biol (2008) 18:R795-804. doi:10.1016/j.cub.2008.07.040

45. Yoshimura T. Neuroendocrine mechanism of seasonal reproduction in birds and mammals. Anim Sci J (2010) 81:403-10. doi:10.1111/j.1740-0929.2010. 00777.x

46. Wieselthier AS, Van Tienhoven A. The effect of thyroidectomy on testicular size and on the photorefractory period in the starling (Sturnus vulgaris L.). J Exp Zool (1972) 179:331-8. doi:10.1002/jez.1401790306

47. Follett BK, Nicholls TJ. Influences of thyroidectomy and thyroxine replacement on photoperiodically controlled reproduction in quail. J Endocrinol (1985) 107:211-21. doi:10.1677/joe.0.1070211

48. Webster JR, Moenter SM, Barrell GK, Lehman MN, Karsch FJ. Role of the thyroid gland in seasonal reproduction. III. Thyroidectomy blocks seasonal suppression of gonadotropin-releasing hormone secretion in sheep. Endocrinology (1991) 129:1635-43. doi:10.1210/endo-129-3-1635

49. Moenter SM, Woodfill CJ, Karsch FJ. Role of the thyroid gland in seasonal reproduction: thyroidectomy blocks seasonal suppression of reproductive neuroendocrine activity in ewes. Endocrinology (1991) 128:1337-44. doi:10.1210/endo-128-3-1337

50. Dardente H. Melatonin-dependent timing of seasonal reproduction by the pars tuberalis: pivotal roles for long daylengths and thyroid hormones. J Neuroendocrinol (2012) 24:249-66. doi:10.1111/j.1365-2826.2011.02250.x

51. Parkinson TJ, Follett BK. Effect of thyroidectomy upon seasonality in rams. J Reprod Fertil (1994) 101:51-8. doi:10.1530/jrf.0.1010051

52. Viguié C, Battaglia DF, Krasa HB, Thrun LA, Karsch FJ. Thyroid hormones act primarily within the brain to promote the seasonal inhibition of luteinizing hormone secretion in the ewe. Endocrinology (1999) 140:1111-7. doi:10.1210/en.140.3.1111

53. Anderson GM, Hardy SL, Valente M, Billings HJ, Connors JM, Goodman RL. Evidence that thyroid hormones act in the ventromedial preoptic area and the premammillary region of the brain to allow the termination of the breeding season in the ewe. Endocrinology (2003) 144:2892-901. doi:10.1210/en.20030322

54. Barrett P, Ebling FJ, Schuhler S, Wilson D, Ross AW, Warner A, et al. Hypothalamic thyroid hormone catabolism acts as a gatekeeper for the seasonal control of body weight and reproduction. Endocrinology (2007) 148:3608-17. doi:10.1210/en.2007-0316

55. Murphy M, Jethwa PH, Warner A, Barrett P, Nilaweera KN, Brameld JM, et al. Effects of manipulating hypothalamic triiodothyronine concentrations on seasonal body weight and torpor cycles in Siberian hamsters. Endocrinology (2012) 153:101-12. doi:10.1210/en.2011-1249

56. Freeman DA, Teubner BJ, Smith CD, Prendergast BJ. Exogenous T3 mimics long day lengths in Siberian hamsters. Am J Physiol Regul Integr Comp Physiol (2007) 292:R2368-72. doi:10.1152/ajpregu.00713.2006

57. Duncan MJ, Goldman BD, Di Pinto MN, Stetson MH. Testicular function and pelage color have different critical daylengths in the Djungarian hamster, Phodopus sungorus sungorus. Endocrinology (1985) 116:424-30. doi:10.1210/endo-116-1-424

58. Maywood ES, Hastings MH. Lesions of the iodomelatonin-binding sites of the mediobasal hypothalamus spare the lactotropic, but block the gonadotropic response of male Syrian hamsters to short photoperiod and to melatonin. Endocrinology (1995) 136:144-53. doi:10.1210/en.136.1.144

59. Galton VA. The roles of the iodothyronine deiodinases in mammalian development. Thyroid (2005) 15:823-34. doi:10.1089/thy.2005.15.823

60. Williams GR. Neurodevelopmental and neurophysiological actions of thyroid hormone. J Neuroendocrinol (2008) 20:784-94. doi:10.1111/j.1365-2826.2008. 01733.x

61. Ebling FJ, Barrett P. The regulation of seasonal changes in food intake and body weight. J Neuroendocrinol (2008) 20:827-33. doi:10.1111/j.1365-2826. 2008.01721.x

62. Lopez M, Varela L, Vazquez MJ, Rodriguez-Cuenca S, Gonzalez CR, Velagapudi VR, et al. Hypothalamic AMPK and fatty acid metabolism mediate thyroid regulation of energy balance. Nat Med (2010) 16:1001-8. doi:10.1038/nm.2207

63. Lopez M, Alvarez CV, Nogueiras R, Dieguez C. Energy balance regulation by thyroid hormones at central level. Trends Mol Med (2013) 19:418-27. doi:10.1016/j.molmed.2013.04.004

64. Kong WM, Martin NM, Smith KL, Gardiner JV, Connoley IP, Stephens DA, et al. Triiodothyronine stimulates food intake via the hypothalamic ventromedial nucleus independent of changes in energy expenditure. Endocrinology (2004) 145:5252-8. doi:10.1210/en.2004-0545

65. Lincoln GA, Rhind SM, Pompolo S, Clarke IJ. Hypothalamic control of photoperiod-induced cycles in food intake, body weight, and metabolic hormones in rams. Am J Physiol Regul Integr Comp Physiol (2001) 281:R76-90.

66. Hulet CV, Shupe WL, Ross T, Richards W. Effects of nutritional environment and ram effect on breeding season in range sheep. Theriogenology (1986) 25:317-23. doi:10.1016/0093-691X(86)90067-1

67. Menassol JB, Collet A, Chesneau D, Malpaux B, Scaramuzzi RJ. The interaction between photoperiod and nutrition and its effects on seasonal rhythms of reproduction in the ewe. Biol Reprod (2012) 86:52. doi:10.1095/biolreprod. 111.092817

68. Walkden-Brown SW, Restall BJ, Norton BW, Scaramuzzi RJ, Martin GB. Effect of nutrition on seasonal patterns of LH, FSH and testosterone concentration, testicular mass, sebaceous gland volume and odour in Australian cashmere goats. J Reprod Fertil (1994) 102:351-60.

69. Zarazaga LA, Celi I, Guzman JL, Malpaux B. The role of nutrition in the regulation of luteinizing hormone secretion by the opioidergic, dopaminergic, and serotonergic systems in female Mediterranean goats. Biol Reprod (2011) 84:447-54. doi:10.1095/biolreprod.110.086520

70. Salazar-Ortiz J, Camous S, Briant C, Lardic L, Chesneau D, Guillaume D. Effects of nutritional cues on the duration of the winter anovulatory phase and on associated hormone levels in adult female Welsh pony horses (Equus caballus). Reprod Biol Endocrinol (2011) 9:130. doi:10.1186/1477-78279- 130

71. Bianco AC, Salvatore D, Gereben B, Berry MJ, Larsen PR. Biochemistry, cellular and molecular biology, and physiological roles of the iodothyronine selenodeiodinases. Endocr Rev (2002) 23:38-89. doi:10.1210/er.23.1.38

72. Lechan RM, Fekete C. Role of thyroid hormone deiodination in the hypothalamus. Thyroid (2005) 15:883-97. doi:10.1089/thy.2005.15.883 
73. St Germain DL, Galton VA, Hernandez A. Minireview: defining the roles of the iodothyronine deiodinases: current concepts and challenges. Endocrinology (2009) 150:1097-107. doi:10.1210/en.2008-1588

74. Tu HM, Legradi G, Bartha T, Salvatore D, Lechan RM, Larsen PR. Regional expression of the type 3 iodothyronine deiodinase messenger ribonucleic acid in the rat central nervous system and its regulation by thyroid hormone. Endocrinology (1999) 140:784-90. doi:10.1210/en.140.2.784

75. Bianco AC, Larsen PR. Cellular and structural biology of the deiodinases. Thyroid (2005) 15:777-86. doi:10.1089/thy.2005.15.777

76. Kalsbeek A, Buijs RM, van Schaik R, Kaptein E, Visser TJ, Doulabi BZ, et al. Daily variations in type II iodothyronine deiodinase activity in the rat brain as controlled by the biological clock. Endocrinology (2005) 146:1418-27. doi:10.1210/en.2004-0763

77. Tu HM, Kim SW, Salvatore D, Bartha T, Legradi G, Larsen PR, et al. Regional distribution of type 2 thyroxine deiodinase messenger ribonucleic acid in rat hypothalamus and pituitary and its regulation by thyroid hormone. Endocrinology (1997) 138:3359-68. doi:10.1210/endo.138.8.5318

78. Guadano-Ferraz A, Obregon MJ, St Germain DL, Bernal J. The type 2 iodothyronine deiodinase is expressed primarily in glial cells in the neonatal rat brain. Proc Natl Acad Sci U S A (1997) 94:10391-6. doi:10.1073/pnas.94.19.10391

79. Nakao N, Takagi T, Iigo M, Tsukamoto T, Yasuo S, Masuda T, et al. Possible involvement of organic anion transporting polypeptide $1 \mathrm{cl}$ in the photoperiodic response of gonads in birds. Endocrinology (2006) 147:1067-73. doi:10.1210/en.2005-1090

80. Ceballos A, Belinchon MM, Sanchez-Mendoza E, Grijota-Martinez C, Dumitrescu AM, Refetoff S, et al. Importance of monocarboxylate transporter 8 for the blood-brain barrier-dependent availability of 3,5,3'-triiodo-Lthyronine. Endocrinology (2009) 150:2491-6. doi:10.1210/en.2008-1616

81. Visser WE, Friesema EC, Visser TJ. Minireview: thyroid hormone transporters: the knowns and the unknowns. Mol Endocrinol (2011) 25:1-14. doi:10.1210/me.2010-0095

82. Herwig A, Wilson D, Logie TJ, Boelen A, Morgan PJ, Mercer JG, et al. Photoperiod and acute energy deficits interact on components of the thyroid hormone system in hypothalamic tanycytes of the Siberian hamster. Am J Physiol Regul Integr Comp Physiol (2009) 296:R1307-15. doi:10.1152/ ajpregu.90755.2008

83. Herwig A, de Vries EM, Bolborea M, Wilson D, Mercer JG, Ebling FJ, et al. Hypothalamic ventricular ependymal thyroid hormone deiodinases are an important element of circannual timing in the Siberian hamster (Phodopus sungorus). PLoS One (2013) 8:e62003. doi:10.1371/journal.pone.0062003

84. Guerra M, Blazquez JL, Peruzzo B, Pelaez B, Rodriguez S, Toranzo D, et al. Cell organization of the rat pars tuberalis. Evidence for open communication between pars tuberalis cells, cerebrospinal fluid and tanycytes. Cell Tissue Res (2010) 339:359-81. doi:10.1007/s00441-009-0885-8

85. Yoshimura $T$, Yasuo $S$, Watanabe $M$, Iigo $M$, Yamamura $T$, Hirunagi $K$, et al. Light-induced hormone conversion of T4 to T3 regulates photoperiodic response of gonads in birds. Nature (2003) 426:178-81. doi:10.1038/ nature 02117

86. Watanabe M, Yasuo S, Watanabe T, Yamamura T, Nakao N, Ebihara S, et al. Photoperiodic regulation of type 2 deiodinase gene in Djungarian hamster: possible homologies between avian and mammalian photoperiodic regulation of reproduction. Endocrinology (2004) 145:1546-9. doi:10.1210/en.2003-1593

87. Watanabe T, Yamamura T, Watanabe M, Yasuo S, Nakao N, Dawson A, et al. Hypothalamic expression of thyroid hormone-activating and -inactivating enzyme genes in relation to photorefractoriness in birds and mammals. Am J Physiol Regul Integr Comp Physiol (2007) 292:R568-72. doi:10.1152/ajpregu. 00521.2006

88. Revel FG, Saboureau M, Pevet P, Mikkelsen JD, Simonneaux V. Melatonin regulates type 2 deiodinase gene expression in the Syrian hamster. Endocrinology (2006) 147:4680-7. doi:10.1210/en.2006-0606

89. Helfer G, Ross AW, Morgan PJ. Neuromedin U partly mimics thyroid stimulating hormone and triggers Wnt/beta-catenin signalling in the photoperiodic response of F344 rats. J Neuroendocrinol (2013) 25:1264-72. doi:10.1111/jne. 12116

90. Yasuo S, Yoshimura T, Ebihara S, Korf HW. Temporal dynamics of type 2 deiodinase expression after melatonin injections in Syrian hamsters. Endocrinology (2007) 148:4385-92. doi:10.1210/en.2007-0497
91. Nakao N, Ono H, Yamamura T, Anraku T, Takagi T, Higashi K, et al. Thyrotrophin in the pars tuberalis triggers photoperiodic response. Nature (2008) 452:317-22. doi:10.1038/nature06738

92. Hanon EA, Lincoln GA, Fustin JM, Dardente H, Masson-Pevet M, Morgan PJ, et al. Ancestral TSH mechanism signals summer in a photoperiodic mammal. Curr Biol (2008) 18:1147-52. doi:10.1016/j.cub.2008.06.076

93. Gereben B, Salvatore D. Pretranslational regulation of type 2 deiodinase. Thyroid (2005) 15:855-64. doi:10.1089/thy.2005.15.855

94. Dupré SM, Dardente H, Birnie MJ, Loudon AS, Lincoln GA, Hazlerigg DG. Evidence for RGS4 modulation of melatonin and thyrotrophin signalling pathways in the pars tuberalis. J Neuroendocrinol (2011) 23:725-32. doi:10.1111/j.1365-2826.2011.02168.x

95. Ebenhoeh O, Hazlerigg D. Modelling a molecular calendar: the seasonal photoperiodic response in mammals. Chaos Solitons Fractals (2013) 50:39-47. doi:10.1016/j.chaos.2012.11.007

96. Hanon EA, Routledge K, Dardente H, Masson-Pevet M, Morgan PJ, Hazlerigg DG. Effect of photoperiod on the thyroid-stimulating hormone neuroendocrine system in the European hamster (Cricetus cricetus). J Neuroendocrinol (2010) 22:51-5. doi:10.1111/j.1365-2826.2009.01937.x

97. Yasuo S, Yoshimura T, Ebihara S, Korf HW. Photoperiodic control of TSHbeta expression in the mammalian pars tuberalis has different impacts on the induction and suppression of the hypothalamo-hypophyseal gonadal axis. J Neuroendocrinol (2010) 22:43-50. doi:10.1111/j.1365-2826.2009.01936.x

98. Krol E, Douglas A, Dardente H, Birnie MJ, Vinne V, Eijer WG, et al. Strong pituitary and hypothalamic responses to photoperiod but not to 6-methoxy2-benzoxazolinone in female common voles (Microtus arvalis). Gen Comp Endocrinol (2012) 179:289-95. doi:10.1016/j.ygcen.2012.09.004

99. Ross AW, Helfer G, Russell L, Darras VM, Morgan PJ. Thyroid hormone signalling genes are regulated by photoperiod in the hypothalamus of F344 rats. PLoS One (2011) 6:e21351. doi:10.1371/journal.pone.0021351

100. Ono H, Hoshino Y, Yasuo S, Watanabe M, Nakane Y, Murai A, et al. Involvement of thyrotropin in photoperiodic signal transduction in mice. Proc Natl Acad Sci U S A (2008) 105:18238-42. doi:10.1073/pnas.0808952105

101. Unfried C, Ansari N, Yasuo S, Korf HW, von Gall C. Impact of melatonin and molecular clockwork components on the expression of thyrotropin beta-chain (Tshb) and the TSH receptor in the mouse pars tuberalis. Endocrinology (2009) 150:4653-62. doi:10.1210/en.2009-0609

102. Hazlerigg D. The evolutionary physiology of photoperiodism in vertebrates. Prog Brain Res (2012) 199:413-22. doi:10.1016/B978-0-444-59427-3.00023-X

103. Nakane Y, Ikegami K, Iigo M, Ono H, Takeda K, Takahashi D, et al. The saccus vasculosus of fish is a sensor of seasonal changes in day length. Nat Commun (2013) 4:2108. doi:10.1038/ncomms3108

104. Necrasov O, Adascalitei E. Contribution à l'étude du sac vasculaire des poissons osseux. Trav Mus Nat His Nat Gr Antipa (1968) 8:465-83.

105. Frost WE, Kipling C. A study of reproduction, early life, weight-length relationship and growth of pike, Esox lucius L., in Windermere. J Anim Ecol (1967) 36:651-93. doi:10.2307/2820

106. Kitano J, Lema SC, Luckenbach JA, Mori S, Kawagishi Y, Kusakabe M, et al. Adaptive divergence in the thyroid hormone signaling pathway in the stickleback radiation. Curr Biol (2010) 20:2124-30. doi:10.1016/j.cub.2010.10. 050

107. O’Brien CS, Bourdo R, Bradshaw WE, Holzapfel CM, Cresko WA. Conservation of the photoperiodic neuroendocrine axis among vertebrates: evidence from the teleost fish, Gasterosteus aculeatus. Gen Comp Endocrinol (2012) 178:19-27. doi:10.1016/j.ygcen.2012.03.010

108. Perfito N, Jeong SY, Silverin B, Calisi RM, Bentley GE, Hau M. Anticipating spring: wild populations of great tits (Parus major) differ in expression of key genes for photoperiodic time measurement. PLoS One (2012) 7:e34997. doi:10.1371/journal.pone.0034997

109. Bentley GE, Tucker S, Chou H, Hau M, Perfito N. Testicular growth and regression are not correlated with Dio2 expression in a wild male songbird, Sturnus vulgaris, exposed to natural changes in photoperiod. Endocrinology (2013) 154:1813-9. doi:10.1210/en.2013-1093

110. Lucas RJ. Mammalian inner retinal photoreception. Curr Biol (2013) 23:R125-33. doi:10.1016/j.cub.2012.12.029

111. Wyse C, Hazlerigg D. Seasonal biology: avian photoreception goes deep. Curr Biol (2009) 19:R685-7. doi:10.1016/j.cub.2009.07.036 
112. Ikegami K, Yoshimura T. Seasonal time measurement during reproduction. J Reprod Dev (2013) 59:327-33. doi:10.1262/jrd.2013-035

113. Kosonsiriluk S, Mauro LJ, Chaiworakul V, Chaiseha Y, El Halawani ME. Photoreceptive oscillators within neurons of the premammillary nucleus (PMM) and seasonal reproduction in temperate zone birds. Gen Comp Endocrinol (2013) 190:149-55. doi:10.1016/j.ygcen.2013.02.015

114. Halford S, Pires SS, Turton M, Zheng L, Gonzalez-Menendez I, Davies WL, et al. VA opsin-based photoreceptors in the hypothalamus of birds. Curr Biol (2009) 19:1396-402. doi:10.1016/j.cub.2009.06.066

115. Nakane Y, Ikegami K, Ono H, Yamamoto N, Yoshida S, Hirunagi K, et al. A mammalian neural tissue opsin (opsin 5) is a deep brain photoreceptor in birds. Proc Natl Acad Sci U S A (2010) 107:15264-8. doi:10.1073/pnas. 1006393107

116. Yamashita T, Ohuchi H, Tomonari S, Ikeda K, Sakai K, Shichida Y. Opn5 is a UV-sensitive bistable pigment that couples with Gi subtype of G protein. Proc Natl Acad Sci U S A (2010) 107:22084-9. doi:10.1073/pnas.1012498107

117. Kang SW, Leclerc B, Kosonsiriluk S, Mauro LJ, Iwasawa A, El Halawani ME. Melanopsin expression in dopamine-melatonin neurons of the premammillary nucleus of the hypothalamus and seasonal reproduction in birds. Neuroscience (2010) 170:200-13. doi:10.1016/j.neuroscience.2010.06.082

118. Follett BK, Maung SL. Rate of testicular maturation, in relation to gonadotropin and testosterone levels, in quail exposed to various artificial photoperiods and to natural daylengths. J Endocrinol (1978) 78:267-80. doi:10.1677/joe.0. 0780267

119. Hoffmann K. The critical photoperiod in the Djungarian hamster Phodopus sungorus. In: Aschoff J, Daan S, Groos G, editors. Vertebrate Circadian Systems. Heidelberg: Springer-Verlag (1982). p. 297-304.

120. Elliott JA. Circadian rhythms and photoperiodic time measurement in mammals. Fed Proc (1976) 35:2339-46.

121. Pittendrigh CS. Circadian surfaces and the diversity of possible roles of circadian organization in photoperiodic induction. Proc Natl Acad Sci U S A (1972) 69:2734-7. doi:10.1073/pnas.69.9.2734

122. Dardente H, Cermakian N. Molecular circadian rhythms in central and peripheral clocks in mammals. Chronobiol Int (2007) 24:195-213. doi:10.1080/ 07420520701283693

123. Dibner C, Schibler U, Albrecht U. The mammalian circadian timing system: organization and coordination of central and peripheral clocks. Annu Rev Physiol (2010) 72:517-49. doi:10.1146/annurev-physiol-021909-135821

124. Mohawk JA, Green CB, Takahashi JS. Central and peripheral circadian clocks in mammals. Annu Rev Neurosci (2012) 35:445-62. doi:10.1146/annurev-neuro060909-153128

125. Messager S, Ross AW, Barrett P, Morgan PJ. Decoding photoperiodic time through Perl and ICER gene amplitude. Proc Natl Acad Sci U S A (1999) 96:9938-43. doi:10.1073/pnas.96.17.9938

126. Dupré SM, Burt DW, Talbot R, Downing A, Mouzaki D, Waddington D, et al. Identification of melatonin-regulated genes in the ovine pituitary pars tuberalis, a target site for seasonal hormone control. Endocrinology (2008) 149:5527-39. doi:10.1210/en.2008-0834

127. Guilding C, Hughes AT, Brown TM, Namvar S, Piggins HD. A riot of rhythms: neuronal and glial circadian oscillators in the mediobasal hypothalamus. $\mathrm{Mol}$ Brain (2009) 2:28. doi:10.1186/1756-6606-2-28

128. Dardente H, Menet JS, Poirel VJ, Streicher D, Gauer F, Vivien-Roels B, et al. Melatonin induces Cryl expression in the pars tuberalis of the rat. Brain Res Mol Brain Res (2003) 114:101-6. doi:10.1016/S0169-328X(03)00134-7

129. Hazlerigg DG, Andersson H, Johnston JD, Lincoln G. Molecular characterization of the long-day response in the Soay sheep, a seasonal mammal. Curr Biol (2004) 14:334-9. doi:10.1016/j.cub.2004.01.057

130. Dardente H, Fortier EE, Martineau V, Cermakian N. Cryptochromes impair phosphorylation of transcriptional activators in the clock: a general mechanism for circadian repression. Biochem J (2007) 402:525-36. doi:10.1042/ BJ20060827

131. Ukai-Tadenuma M, Yamada RG, Xu H, Ripperger JA, Liu AC, Ueda HR. Delay in feedback repression by cryptochrome 1 is required for circadian clock function. Cell (2011) 144:268-81. doi:10.1016/j.cell.2010.12.019

132. Maywood ES, Drynan L, Chesham JE, Edwards MD, Dardente H, Fustin JM, et al. Analysis of core circadian feedback loop in suprachiasmatic nucleus of mCryl-luc transgenic reporter mouse. Proc Natl Acad Sci U S A (2013) 110:9547-52. doi:10.1073/pnas.1220894110
133. Fustin JM, Dardente H, Wagner GC, Carter DA, Johnston JD, Lincoln GA, et al. Egr1 involvement in evening gene regulation by melatonin. FASEB J (2009) 23:764-73. doi:10.1096/fj.08-121467

134. Unfried C, Burbach G, Korf HW, von Gall C. Melatonin receptor 1-dependent gene expression in the mouse pars tuberalis as revealed by cDNA microarray analysis and in situ hybridization. J Pineal Res (2010) 48:148-56. doi:10.1111/ j.1600-079X.2009.00738.x

135. West A, Dupré SM, Yu L, Paton IR, Miedzinska K, McNeilly AS, et al. Npas4 is activated by melatonin, and drives the clock gene Cryl in the ovine pars tuberalis. Mol Endocrinol (2013) 27:979-89. doi:10.1210/me.2012-1366

136. Lincoln G, Messager S, Andersson H, Hazlerigg D. Temporal expression of seven clock genes in the suprachiasmatic nucleus and the pars tuberalis of the sheep: evidence for an internal coincidence timer. Proc Natl Acad Sci U S A (2002) 99:13890-5. doi:10.1073/pnas.212517599

137. Yasuo S, Watanabe M, Tsukada A, Takagi T, Iigo M, Shimada K, et al. Photoinducible phase-specific light induction of Cryl gene in the pars tuberalis of Japanese quail. Endocrinology (2004) 145:1612-6. doi:10.1210/en.2003-1285

138. Dardente H, Wyse CA, Birnie MJ, Dupré SM, Loudon AS, Lincoln GA, et al. A molecular switch for photoperiod responsiveness in mammals. Curr Biol (2010) 20:2193-8. doi:10.1016/j.cub.2010.10.048

139. Masumoto KH, Ukai-Tadenuma M, Kasukawa T, Nagano M, Uno KD, Tsujino $\mathrm{K}$, et al. Acute induction of Eya3 by late-night light stimulation triggers TSHbeta expression in photoperiodism. Curr Biol (2010) 20:2199-206. doi:10.1016/j.cub.2010.11.038

140. Tsujino K, Narumi R, Masumoto KH, Susaki EA, Shinohara Y, Abe T, et al. Establishment of TSH beta real-time monitoring system in mammalian photoperiodism. Genes Cells (2013) 18:575-88. doi:10.1111/gtc.12063

141. Helfer G, Ross AW, Russell L, Thomson LM, Shearer KD, Goodman TH, et al. Photoperiod regulates vitamin A and Wnt/beta-catenin signaling in F344 rats. Endocrinology (2012) 153:815-24. doi:10.1210/en.2011-1792

142. Ross AW, Bell LM, Littlewood PA, Mercer JG, Barrett P, Morgan PJ. Temporal changes in gene expression in the arcuate nucleus precede seasonal responses in adiposity and reproduction. Endocrinology (2005) 146:1940-7. doi:10.1210/en.2004-1538

143. Barrett P, Ross AW, Balik A, Littlewood PA, Mercer JG, Moar KM, et al. Photoperiodic regulation of histamine $\mathrm{H} 3$ receptor and VGF messenger ribonucleic acid in the arcuate nucleus of the Siberian hamster. Endocrinology (2005) 146:1930-9. doi:10.1210/en.2004-1452

144. Klosen P, Sebert ME, Rasri K, Laran-Chich MP, Simonneaux V. TSH restores a summer phenotype in photoinhibited mammals via the RF-amides RFRP3 and kisspeptin. FASEB J (2013) 27:2677-86. doi:10.1096/fj.13-229559

145. Morgan PJ, Hazlerigg DG. Photoperiodic signalling through the melatonin receptor turns full circle. J Neuroendocrinol (2008) 20:820-6. doi:10.1111/j. 1365-2826.2008.01724.x

146. Shearer KD, Goodman TH, Ross AW, Reilly L, Morgan PJ, McCaffery PJ. Photoperiodic regulation of retinoic acid signaling in the hypothalamus. $\mathrm{J} \mathrm{Neu}$ rochem (2010) 112:246-57. doi:10.1111/j.1471-4159.2009.06455.x

147. Bechtold DA, Sidibe A, Saer BR, Li J, Hand LE, Ivanova EA, et al. A role for the melatonin-related receptor GPR50 in leptin signaling, adaptive thermogenesis, and torpor. Curr Biol (2012) 22:70-7. doi:10.1016/j.cub.2011.11.043

148. Hand LE, Saer BR, Hui ST, Jinnah HA, Steinlechner S, Loudon AS, et al. Induction of the metabolic regulator Txnip in fasting-induced and natural torpor. Endocrinology (2013) 154:2081-91. doi:10.1210/en.2012-2051

149. Scherbarth F, Steinlechner S. Endocrine mechanisms of seasonal adaptation in small mammals: from early results to present understanding. J Comp Physiol B (2010) 180:935-52. doi:10.1007/s00360-010-0498-2

150. Bolborea M, Dale N. Hypothalamic tanycytes: potential roles in the control of feeding and energy balance. Trends Neurosci (2013) 36:91-100. doi:10.1016/j. tins.2012.12.008

151. Paul MJ, Zucker I, Schwartz WJ. Tracking the seasons: the internal calendars of vertebrates. Philos Trans R Soc Lond B Biol Sci (2008) 363:341-61. doi:10.1098/rstb.2007.2143

152. Follett BK, Nicholls TJ. Photorefractoriness in Japanese quail: possible involvement of the thyroid gland. J Exp Zool (1984) 232:573-80. doi:10.1002/jez. 1402320325

153. Hazlerigg DG, Lincoln GA. Hypothesis: cyclical histogenesis is the basis of circannual timing. J Biol Rhythms (2011) 26:471-85. doi:10.1177/ 0748730411420812 
154. Migaud M, Batailler M, Pillon D, Franceschini I, Malpaux B. Seasonal changes in cell proliferation in the adult sheep brain and pars tuberalis. J Biol Rhythms (2011) 26:486-96. doi:10.1177/0748730411420062

155. Lee DA, Blackshaw S. Functional implications of hypothalamic neurogenesis in the adult mammalian brain. Int J Dev Neurosci (2012) 30:615-21. doi:10.1016/j.ijdevneu.2012.07.003

156. Hazlerigg DG, Wyse CA, Dardente H, Hanon EA, Lincoln GA. Photoperiodic variation in CD45-positive cells and cell proliferation in the mediobasal hypothalamus of the Soay sheep. Chronobiol Int (2013) 30:548-58. doi:10.3109/ 07420528.2012.754450

157. Saenz de Miera C, Hanon EA, Dardente H, Birnie M, Simonneaux V, Lincoln GA, et al. Circannual variation in thyroid hormone deiodinases in a short-day breeder. J Neuroendocrinol (2013) 25:412-21. doi:10.1111/jne.12013

158. Murphy M, Ebling FJ. The role of hypothalamic tri-iodothyronine availability in seasonal regulation of energy balance and body weight. J Thyroid Res (2011) 2011:387562. doi:10.4061/2011/387562

159. Simonneaux V, Bur I, Ancel C, Ansel L, Klosen P. A kiss for daily and seasonal reproduction. Prog Brain Res (2012) 199:423-37. doi:10.1016/B978-0444-59427-3.00024- 1

160. Clarke IJ, Caraty A. Kisspeptin and seasonality of reproduction. Adv Exp Med Biol (2013) 784:411-30. doi:10.1007/978-1-4614-6199-9_19

161. Beltramo M, Dardente H, Cayla X, Caraty A. Cellular mechanisms and integrative timing of neuroendocrine control of $\mathrm{GnRH}$ secretion by kisspeptin. $\mathrm{Mol}$ Cell Endocrinol (2014) 382:387-99. doi:10.1016/j.mce.2013.10.015

162. Oakley AE, Clifton DK, Steiner RA. Kisspeptin signaling in the brain. Endocr Rev (2009) 30:713-43. doi:10.1210/er.2009-0005

163. Hill JW, Alreja M, Elias CF. From precocious puberty to infertility: metabolic control of the reproductive function. Front Endocrinol (Lausanne) (2013) 4:43. doi:10.3389/fendo.2013.00043

164. Ebling FJ, Foster DL. Pineal melatonin rhythms and the timing of puberty in mammals. Experientia (1989) 45:946-54. doi:10.1007/BF01953052

165. Ebling FJ. Photoperiodic regulation of puberty in seasonal species. Mol Cell Endocrinol (2010) 324:95-101. doi:10.1016/j.mce.2010.03.018

166. Clarke IJ, Smith JT, Henry BA, Oldfield BJ, Stefanidis A, Millar RP, et al. Gonadotropin-inhibitory hormone is a hypothalamic peptide that provides a molecular switch between reproduction and feeding. Neuroendocrinology (2012) 95:305-16. doi:10.1159/000332822

167. Kirby ED, Geraghty AC, Ubuka T, Bentley GE, Kaufer D. Stress increases putative gonadotropin inhibitory hormone and decreases luteinizing hormone in male rats. Proc Natl Acad Sci U S A (2009) 106:11324-9. doi:10.1073/pnas. 0901176106

168. Clarke IJ, Sari IP, Qi Y, Smith JT, Parkington HC, Ubuka T, et al. Potent action of RFamide-related peptide- 3 on pituitary gonadotropes indicative of a hypophysiotropic role in the negative regulation of gonadotropin secretion. Endocrinology (2008) 149:5811-21. doi:10.1210/en.2008-0575
169. Caraty A, Blomenrohr M, Vogel GM, Lomet D, Briant C, Beltramo M. RF9 powerfully stimulates gonadotropin secretion in the ewe: evidence for a seasonal threshold of sensitivity. J Neuroendocrinol (2012) 24:725-36. doi:10.1111/j. 1365-2826.2012.02283.x

170. Ancel C, Bentsen AH, Sebert ME, Tena-Sempere M, Mikkelsen JD, Simonneaux V. Stimulatory effect of RFRP-3 on the gonadotropic axis in the male Syrian hamster: the exception proves the rule. Endocrinology (2012) 153:1352-63. doi:10.1210/en.2011-1622

171. Ubuka T, Inoue K, Fukuda Y, Mizuno T, Ukena K, Kriegsfeld LJ, et al. Identification, expression, and physiological functions of Siberian hamster gonadotropin-inhibitory hormone. Endocrinology (2012) 153:373-85. doi:10. 1210/en.2011-1110

172. Tsutsui K, Ubuka T, Bentley GE, Kriegsfeld LJ. Review: regulatory mechanisms of gonadotropin-inhibitory hormone $(\mathrm{GnIH})$ synthesis and release in photoperiodic animals. Front Neurosci (2013) 7:60. doi:10.3389/fnins.2013. 00060

173. Osugi T, Ohtaki N, Sunakawa Y, Son YL, Ohkubo M, Iigo M, et al. Molecular evolution of kiss2 genes and peptides in vertebrates. Endocrinology (2013) 154:4270-80. doi:10.1210/en.2012-2267

174. Kriegsfeld LJ. Driving reproduction: RFamide peptides behind the wheel. Horm Behav (2006) 50:655-66. doi:10.1016/j.yhbeh.2006.06.004

175. Simonneaux V, Ansel L, Revel FG, Klosen P, Pevet P, Mikkelsen JD. Kisspeptin and the seasonal control of reproduction in hamsters. Peptides (2009) 30:146-53. doi:10.1016/j.peptides.2008.06.006

176. Henson JR, Carter SN, Freeman DA. Exogenous T(3) elicits long day-like alterations in testis size and the RFamides kisspeptin and gonadotropin-inhibitory hormone in short-day Siberian hamsters. J Biol Rhythms (2013) 28:193-200. doi:10.1177/0748730413487974

Conflict of Interest Statement: The authors declare that the research was conducted in the absence of any commercial or financial relationships that could be construed as a potential conflict of interest.

Received: 18 December 2013; paper pending published: 03 February 2014; accepted: 10 February 2014; published online: 26 February 2014.

Citation: Dardente H, Hazlerigg DG and Ebling FJP (2014) Thyroid hormone and seasonal rhythmicity. Front. Endocrinol. 5:19. doi: 10.3389/fendo.2014.00019

This article was submitted to Thyroid Endocrinology, a section of the journal Frontiers in Endocrinology.

Copyright (C) 2014 Dardente, Hazlerigg and Ebling. This is an open-access article distributed under the terms of the Creative Commons Attribution License (CC BY). The use, distribution or reproduction in other forums is permitted, provided the original author(s) or licensor are credited and that the original publication in this journal is cited, in accordance with accepted academic practice. No use, distribution or reproduction is permitted which does not comply with these terms. 